\title{
THE CONTRARIES' PROGRESSION: ROMANTIC IRONY IN THE INTRODUCTORY POEMS OF WILLIAM BLAKE'S SONGS OF INNOCENCE AND OF EXPERIENCE
}

William Weber Wanderlinde $\mathrm{e}^{\mathrm{1}^{*}}$ Universidade Federal de Santa Catarina, Florianópolis, SC, Brazil

\begin{abstract}
In the vast bibliography on William Blake, scholars usually comment on the irony in his poetic works, but seldom they do explain such comments. This paper is an attempt to understand the ironies present in some poems of Songs of Innocence and of Experience, while at the same time taking into consideration the dialectical quality of Blake's thought. To do so, the concept of Romantic irony, developed by Friedrich Schlegel, is used, as it is also dialectical in its nature. In order to illustrate how Romantic irony is used to read the volume, an analysis of the introductory poems of each section, along with "Earth's Answer" (the second introduction's coda) and two plates which illustrate these poems, is made. The readings show some affinities between Blake's and Schlegel's way of thinking.

Keywords: William Blake; Friedrich Schlegel; Irony; Romantic irony
\end{abstract}

\footnotetext{
Doctoral student at Programa de Pós-graduação em Inglês (PPGI) at Universidade Federal de Santa Catarina (UFSC). This work is one of the results of his Master's thesis, "William Blake's 'Contraries' as dialectical irony in Songs of Innocence and of Experience," finished in February 2020, having professor Maria Rita Drummond Viana (UFSC) as his advisor. This study was financed in part by the Coordenação de Aperfeiçoamento de Pessoal de Nível Superior - Brasil (CAPES) - Finance Code 001. E-mail: willww88@gmail.com. ORCID: https://orcid. org/0000-0003-3438-2361.
} 


\section{Scholars and Irony in Songs of Innocence and of Experience}

If one revises the vast bibliography on William Blake (1757-1827), several hints about irony in his poetic works will appear. Indeed, a look at The Marriage of Heaven and Hell (1793), Blake's satirical manifesto where he expounds some of his views, will easily yield to the reader an ironic work, since the contrast between Heaven and Hell seems so counterintuitive. In his later books, usually called the Prophetic Books, such irony is harder to grasp, since these works involve a complex mythology. But still it is explained occasionally, for instance by Harold Bloom, either in his thorough analysis of Blake's poetic texts conducted in Blake's Apocalypse (1963), or in his notes included in the now standard edition of Blake's texts, The Complete Poetry \& Prose of William Blake (1982), edited by David V. Erdman.

Arguably Blake's most famous book, Songs of Innocence and of Experience $(1794)^{1}$ is also pointed out by scholars as including some degree of irony. When considering the poems included in this volume, however, critics commonly affirm their ironical attitude, but not thoroughly explain it. This is exemplified by Erdman, in what is one of the essential books on William Blake, Blake: Prophet Against Empire (2015):

There are layers of innuendo [in the Songs] that reveal themselves only under careful and repeated examination, and the degree of tension between the surface meaning and the satiric implications depends much on the intellectual distance between the singer and the real author, Blake. (Erdman 118)

While Erdman's statement is on point, and even guides the interpretation of several scholars, Erdman does not spend much time giving support to his argument, e.g. showing in the intricacies of a close reading of a given poem its truth.

On the other hand, Bloom points out instances of irony in different poems of the Songs. However, Bloom spends much more print on Blake's Prophetic Books, dismissing some Songs with one or two quick paragraphs-such as "The Ecchoing Green" (Blake's Apocalypse, 40-41). While his book is invaluable in the complex endeavor of interpreting Blake's later works, which he treats as the apex of Blake's art, Bloom's treatment of the irony in Songs, even if at times revealing, is somehow lacking. Likewise, in his notes for The Complete Poetry and Prose of William Blake, he completely refrains from commenting on Songs, focusing mostly on the Prophetic Books.

This is not to disqualify Erdman's interpretation carried out in Blake: Prophet Against Empire, a much needed and thorough historical interpretation of Blake's poetic texts; nor is it to disqualify Bloom's interpretations in Blake's Apocalypse, a helpful and comprehensive reading of Blake, illuminating several aspects of his later, more difficult work. Instead, this shows the seeming agreement regarding the presence of irony in Songs, while at the same time the apparent dismissal by these critics of the necessity to point out such ironies, as if they were self-evident. When compared either with Milton or Jerusalem, Songs indeed seems to be selfevident. But its coexistence with such intricate works cannot refrain one from 
thoroughly analyzing its "minute particulars" (Blake 185). A brief overview of how Songs came to be will enlighten some points.

Songs was not published at first the same way it was subsequently published from 1794 on. To publish, in fact, is not exactly the verb to be used in such situation, since Blake himself was in charge of writing, engraving, pressing, and ultimately selling his volumes, having the help of his wife Catherine on the printing process (Damrosch 2016, 19). His method, named by him "illuminated printing," was unique up to that point (Viscomi and Eaves 2004, 41). Illuminated printing was the result of the printing of Blake's meticulously engraved copper plates, which combined designs and engraved texts. Such prints, which did not use typography and were afterwards painted, ${ }^{2}$ were then combined in volumes to be sold.

Songs of Innocence, a collection of poems first printed in 1789, was one of Blake's first works using this method. This is what is now included as the first section of Songs of Innocence and of Experience. According to Michael Phillips, such work seems to be a book for children: the poems are short, the syntax and the rhyme scheme are mostly simple, nursery-rhyme-like even, and the themes are usually related to children. Phillips, however, notices something that puts Songs of Innocence in a different perspective. According to him, books for children which were published around the same time had striking differences from Blake's volume. Evidently, they lacked Blake's method of illuminated printing, but such difference is not the most important: other books combined engravings and texts (in those cases typography) on the same page-certainly without the finesse of Blake's plates. Different from Songs of Innocence, however, these books had engravings which emphasized "moral uprightness," with poems accordingly following the same vein (Phillips 2014, 109). The engravings portrayed scenes set indoors, with adults teaching attentive children dressed as little adults in an upper-class environment. Such scenes are very different from the mostly outdoor scenes of Songs of Innocence, with lush vegetation, grazing sheep, and happy children playing.

By now it is already possible to perceive in this apparently naive volume a critique, arguably an ironic one, not only of books for children of the time, but of the way children were perceived by society. The cover of the volume is enlightening: ${ }^{3}$ 


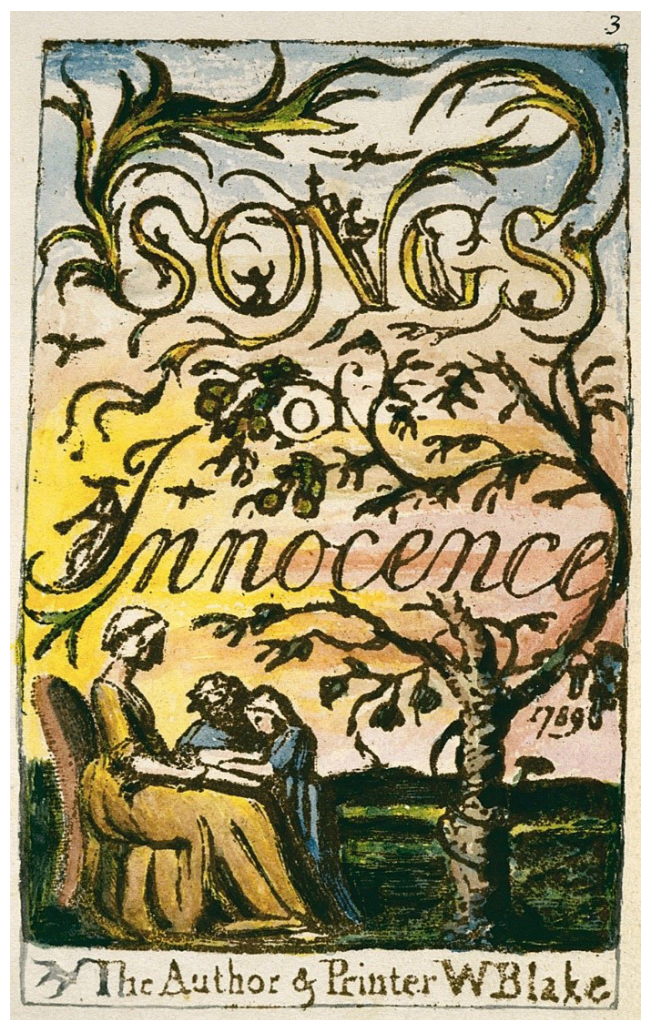

Figure 1. L 3 - Songs of Innocence Cover

Source: www.blakearchive.org/copy/songsie.l?descId=songsie.l.illbk.03

Here an outdoor scene is depicted, and the title of the volume somehow merges with the intricately designed tree. Three persons in simple, peasant clothes appear: the adult holds a book, while the children look at it. They are not guided by the adult, who let them explore the book by themselves-something very different from the morality expressed in the books for children of the period. Instead, the adults will learn with the children and other innocent characters depicted throughout the book. This is, then, a subversion of moral and educational standards of the period, ironically emphasizing a pastoral mode, and focusing on play, joy, and innocence. Nevertheless, the mood of the poems seems to be far from irony. Take, for instance, “The Ecchoing Green," in which merry kids play all day long while adults nostalgically watch and remember their time of youth. There is a sincerity in its innocence that seemingly fails to feel ironic. This, however, can be questioned, as Songs of Experience enters into the discussion.

Four years after printing Songs of Innocence, Blake printed Songs of Experience (1793), another volume of poems, with striking correspondences with the earlier volume (Blake 790-791). Those were not random, since from 1794 on Blake would print both volumes together as Songs of Innocence and of Experience, adding the following cover: 


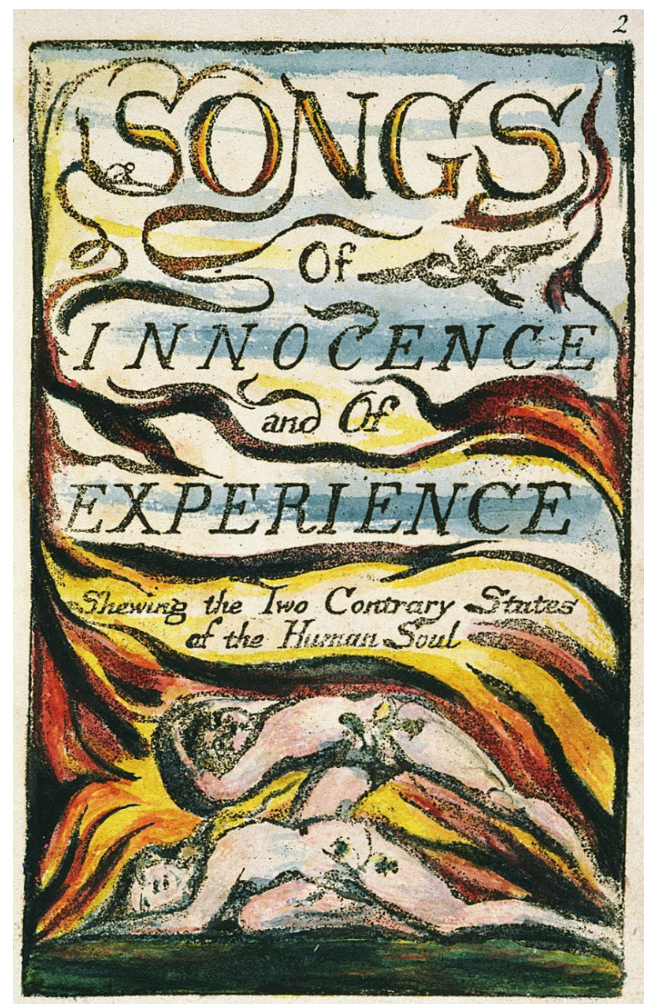

Figure 2. L 2 - Main Cover

Source: www.blakearchive.org/copy/songsie.l?descId=songsie.l.illbk.02

Both volumes, now combined, were meant to be read together. With this, the reading of the first section, "Songs of Innocence" (i.e. the earlier volume Songs of Innocence), is substantially changed.

When confronted with this new cover, a scene of Adam and Eve after the fall is depicted, with fig leaves covering their pudenda. The lower part of the plate is dominated by the fire and desperation of the Adamic couple, while the upper part suits the natural scenery present in the first section. If for Songs of Innocence the contrast was created with other books for children, now the contrast happens within the volume of Songs itself, indeed in the cover itself, as both halves contend for prominence. The newly added subtitle ("Shewing the Two Contrary States of the Human Soul") emphasizes the contrapuntal aspect of the volume, attributing to each section its own psychological state.

If "Innocence"4 brings a sincere, optimistic take on childhood and on life, expressing throughout joie de vivre, "Experience" brings a pensive, melancholic, sometimes rebellious and desperate mood, more easily associated with maturity. Bloom notes a distinction between Innocence and Experience in the way through which truth is perceived: to him, the state of Innocence "is that state of the human soul in which we ascertain truth as immediate knowledge, for the knower and the known share an unsought natural harmony" (Blake's Apocalypse 46). Experience, on the other hand, is the state of utter suspicion, which can be sometimes so pervasive as to bring despair. This distinction makes more evident the way through which Innocence and Experience work as contraries, as the book's subtitle indicates.

The contrast between both sections is enhanced when the mirror poems are taken in consideration. The mirror poems are pairs of poems, one appearing 
in each section of the book, that deal with the same subject (sometimes even having the same title, such as both poems titled "The Chimney Sweeper," one from "Innocence" and the other from "Experience") or with contraries (as in "The Lamb" and "The Tyger").

Such poems invite a side-by-side reading. This is what D. G. Gillham does in Blake's Contrary States (2009). Gillham identifies every pair of mirror poems in the book (which includes questionable choices, such as "The Ecchoing Green" and "London"), and makes a reading of them side by side. For him, each poem dramatizes the state of the section in which it is included. Allowing the poems to have this dramatic quality, turning them in a sort of dramatic monologue, is a vital step in the reading of these poems, especially when the idea of the contrast within the volume is considered. However, I depart from some of Gillham's assumptions, the most important being the hierarchy Gillham creates between Innocence and Experience, prioritizing the first state (7).

Gillham's is a polemical view, as other commentators tend to more clearly problematize the contrary states, and treat them in a dialectical way suited to the aforementioned distinction of "truth as immediate knowledge" and utter suspicion (Bloom Blake's Apocalypse 46). Blake himself would extend and make his psychological categories more complex in his later books. In my view, the possibility of what Bloom calls an "organized, higher innocence" seems accurate (Blake's Apocalypse 20). Martin K. Nurmi explains this further:

To end in the state of Experience would be to end in cynicism and perhaps despair. But in Blake's scheme there is a third state, that of wise Innocence, which synthesizes the first two [...] It is a state of 'organized' Innocence [...] a state in which the bitterness of Experience has been met, absorbed, and transcended. (qtd. in Simpson 1979, 216)

This higher Innocence is a sort of dialectical, positive interplay between both Innocence and Experience. Such way of understanding this relation suits well Blake's aphorism in The Marriage for Heaven and Hell: "Without Contraries is no progression" (Blake 34). With this in mind, a reading which, like Gillham's, treats the poems as dramatic monologues, but also takes into account the dialectical aspect of the two contraries, will possibly be closer to the logic of the volume itself.

Another aspect which Gillham does not consider, nor most of the commentators cited up to now, is that Blake's poems should be treated as a composite art, ${ }^{5}$ which merges designs and text in each plate. This composite aspect creates tensions inside each plate, and is a way for readers to ponder about the relations between Innocence and Experience. More recent criticism must take into account such characteristic of Blake's works that makes them so unique. If for earlier interpretations a strict consideration of the text was possible because of the difficulty to access facsimile editions of Blake's works, nowadays, with The William Blake Archive website, such difficulty can be neglected. This is what Leo Damrosch does in Eternity's Sunrise (2016), a recent book on Blake which brings contemporary theoretical approaches to update the interpretation of Blake's 
oeuvre. His focus on earlier (and arguably more accessible) works by Blake, along with his fresh views and the merging view of Blake as both poet and painter, are enriching and helpful in the consideration of the dialectical aspect of Songs.

\section{Friedrich Schlegel's Romantic irony as dialectical irony}

I considered briefly entryways into an interpretation of the Songs which will take into account its irony. The ironical contrasts can work inside each isolated poem, or in the contrast of the mirror poems. I will follow here this last path, and in order to do so a concept of irony which brings to the forefront a dialectical approach will be especially useful. For these purposes, then, the Romantic irony developed by Friedrich Schlegel (1772-1829) is fitting. It should be noted that, even though they were contemporaries, Schlegel and Blake most probably never read each other's works. Blake was almost neglected in his lifetime, and Schlegel's thought circulated Europe with Madame de Staël's On Germany (1813) decades after the completion of Songs.

Firstly, it should be taken into account that the concept of Romantic irony developed by Schlegel is not like the stable ironies of Wayne C. Booth in A Rhetoric of Irony (1975); nor is it like the verbal ironies or dramatic ironies described, for instance, by D. C. Muecke (2008, 30), and Claire Colebrook $(2008,13)$. Those are figures of speech, and Romantic irony is not. This means that it cannot be spotted in a piece of close reading, and then "reconstructed" so as to achieve its "real" meaning (Booth 5-6). Romantic irony deviates from irony as textual tropes, because it is personal, not textual. Schlegel understood irony "as something like a human condition or predicament" (Colebrook 47). Since for him human life is a process, a continuous becoming, there is always a distance, which he would argue is an ironic one, between the subject and what he/she produces. This product, poetry, is the result of a fall from the life of becoming, to a fixed, final form. Poetry, then, is not mimetic in the usual sense of copying reality. Instead, poetry itself creates, copying not something, but instead copying the process; not the being, but the becoming (Colebrook 47-48).

The philosophical background in which this kind of thinking was being done is relevant for understanding the concept. Schlegel was part of a group of thinkers and writers from the town of Jena (now part of Germany), which included Novalis and Schleiermacher, later identified as Jena Romanticism or Frühromantik. Walter Benjamin notes that, as thinkers of the German idealism, following and improving on Fichte's theory of knowledge, the Jena Romantics put a great importance in the becoming as opposed to being $(2018,30-31)$. The latter was for them too elusive, and could only be apprehended through the becoming. The focus on becoming made the non-static aspects of philosophy prominent, hence the importance of development and dialectics for these thinkers.

The dialectical aspect of Romantic irony is of special interest. As Steven A. Alford remarks, "dialectical irony is for many critics another name for the Romantic irony" $(1984,22)$. Alford means by this a type of irony something very 
different from an ironical remark like "what a beautiful day!" in a stormy weather. Dialectical irony is contradictory, or, as Schlegel puts it, "irony is the form of paradox" (Schlegel 1971, 149). In this type of irony, both the literal and the reconstructed ironic readings are accepted. The final meaning is itself paradoxical, as it is a synthesis of both possibilities. This type of irony is undecidable (using Booth's term), since the reader cannot choose between thesis and antithesis, but instead vacillates between them in a dialectical way.

Anotherrelevantaspect of theundecidabilityofRomanticironyisitsopposition to reason, an important Romantic value, which Blake also cultivated. Romantic irony's paradoxes bring to texts an unreasonableness that cannot be resolved through logic - at least not through deductive logic. This unreasonableness must instead be embraced by the imagination. When, in Jerusalem, Blake says that "Imagination the real \& eternal World of which this Vegetable Universe is but a faint shadow" (Blake 231), he is putting the imagination above our fallen world ("Vegetable Universe"), similar to the way Jena Romantics think. Their exaltation of imagination contrasts with what was until then the accepted Enlightenment idea of logic and reason as what was above individual human beings.

Schlegel's concept of Romantic irony, with the aforementioned philosophical background, is developed throughout several fragments, small pieces of writing - a sentence, a couple of paragraphs. Some of them were published in the influential literary magazine Athenaeum (run by Schlegel and his brother), while others, from his notebooks, remained unpublished until the twentieth century. With access to all Schlegel's fragments, the concept would be re-appraised by thinkers such as Walter Benjamin and Michel Foucault, and the negative view on it established by Hegel, which was dominant until the first half of the twentieth century, would be reconsidered (Seligmann-Silva 2018, 9-10).

Schlegel scholar Constantino de Luz Medeiros retraces through these fragments key terms for Schlegel. He notes that Schlegel called attention to terms such as "parabasis" and "buffoon," which are connected to the literary tradition (Medeiros 2014, 56). Parabasis is a term used to define a section in the Greek comedies in which the chorus talks directly to the audience (Medeiros 58). This section was connected to the point of view of the author, in which he reflected upon the events of the play being enacted (Cuddon 2013, 509). The parabasis is, then, a creative counterpoint of the author on his/her creation, a metacommentary as a way to critically engage with the play while it is happening. Another term Schlegel used, the "buffoon," was a stock character in the dramatic genre commedia dellarte (Medeiros 56). The genre was a "form of improvised comic performance popular between the 16th and 18th centuries (...) in Europe, acted in masks by travelling companies of professional actors each of whom specialized in a stock character" (Baldick 2001, 46). The buffoon's function was to prepare the scene for the entrance of other characters and make transitions in the plot of the plays, improvising jokes and commenting on what had happened until then. Medeiros also connects the buffoon with "the role of the dramatist" because of his self-critical stance. Both parabasis and the buffoon figure come 
from drama, more specifically from comedies, and both have to do with a critical stance towards the play being enacted. They are, in this sense, authorial interventions in the text, a creative and critical act at the same time. For Schlegel, a "permanent parabasis" was needed, meaning that a constant critical reflection on the act of creation was necessary (Schlegel 29).

For this process to work, Medeiros identifies in Schlegel's fragments three steps for the act of creation: "'self-creation,' 'self-annihilation,' and 'selfrestriction"' (58). The "self-creation" is the step in which the author is completely committed to his/her intuition: the author is "naive, enthusiastic, inspired, imaginative"9 (Muecke 41). This step carries with it the problem of the closeness of the subject to the author. The work of art shackles the author's liberty in this step, because of the closeness which makes the author see too narrowly. "Selfannihilation," on the other hand, is the critical stance, through which the author is able to criticize and correct his/her own work of art. These steps complement each other, and both are necessary for the work of art to succeed.

Schlegel's famous $37^{\text {th }}$ fragment makes these concepts of "self-creation" and "self-annihilation" clearer:

In order to write well about something, one shouldn't be interested in it any longer. To express an idea with due circumspection, one must have relegated it wholly to one's past; one must no longer be preoccupied with it. As long as the artist is in the process of discovery and inspiration, he is in a state which, as far as communication is concerned, is at the very least intolerant. He wants to blurt out everything, which is a fault of young geniuses or a legitimate prejudice of old bunglers. And so he fails to recognize the value and the dignity of self-restriction, which is after all, for the artist as well as the man, the first and the last, the most necessary and the highest duty. (Schlegel 146-147)

In the first sentence, Schlegel signals to the importance of "self-annihilation." The next sentences warn about the dangers of relying too heavily on "selfcreation," noting the "illiberal state" caused by this. This "illiberal state" is exactly what his last concept, "self-restriction," comes to change. "Self-restriction" is a synthesis of both earlier steps, and represents a salutary distancing between the subject and the artist.

These concepts can also be linked to two concepts developed by Friedrich Schiller in "Über naive und sentimentalische Dichtung"10 (1795), as they were important for Schlegel to think about self-creation and self-annihilation. As Orhan Pamuk succinctly explains, the naive poets are "unaware of the techniques they are using: they write spontaneously, as if they were carrying out a perfectly natural act, oblivious to the operations and calculations they are performing in their head" (Pamuk 2011, 13); sentimental poets, on the other hand, "are fascinated by the artificiality of the text and its failure to attain reality, and [...] pay close attention to the methods used in writing" (13). Even with the similarity between Schiller's concepts and both self-creation and self-annihilation, it needs to be emphasized that Schiller's two concepts work as a dichotomy, and not as a 
dialectical process. Hence, there is no equivalent to self-restriction in Schiller.

Schlegel's three concepts fairly explain how his concept of Romantic irony works. Its focus on the artistic creation and on the writer need not be a hindrance here. Although I will use it to read Blake's poems, and not to speculate about his creative process, a similar dialectical approach can be used. Also, the dialectical logic of Schlegel's concept fits nicely with an understanding of Blake's Innocence and Experience as contraries which progress. Before explaining how this will work, however, I consider first one of the possibilities of interpreting Schlegel's concept which I will not pursue here. With Schlegel's insistence on "permanent parabasis," it is possible to understand Romantic irony as some sort of constant breaking of the fourth wall. Germanist Raymond Immerwahr is against this view:

Once one pays heed to Schlegel's own explanation of the phrase "Selbstschöpfung und Selbstvernichtung" [self-creation and selfannihilation], it becomes apparent that he is not referring to the outright destruction of objective illusion. His grossly extravagant, deliberately sensational metaphors and cultivated oracular incoherence have given rise to misunderstandings such as this and obscured the actual intent of his words. $(1951,179)$

Such "outright destruction of objective illusion," which was used, for instance, to connect Romantic irony with fellow Jena Romantic Ludwig Tieck's plays, will not be considered here.

The method I will use to read the mirror poems is as follows: on the first step, a reading of the poem from "Innocence" will be made. This step is the Innocent reading, which is related to Schlegel's self-creation. In this step the poem from "Innocence" will be read so as to bring to the fore its aspects of Innocence, i.e. of intuition, naivete, a childlike attitude towards life. On the second step, related to self-annihilation, a reading of the poem from "Experience" will be carried out. This Experienced reading, like Schlegel's self-annihilation, will criticize several aspects of the first reading. The third and last moment of the analysis is where a synthesis occurs, and it is related to self-restriction. This synthesis is an attempt to transcend Innocence and Experience to achieve "a higher Innocence" (Bloom Visionary Company 1971, 20). Such method can be used to read any pair of mirror poems in the book. In order to illustrate how such reading can be achieved, the pair of introductory poems of each section was chosen.

It should be noted that the poems can (and in fact should) also be read on their own, so as to reveal the ironic tensions within them. This is not the path I will pursue here, since the ironic contrast is going to take place between the mirror poems. This is why the first step (the Innocent reading of the poem from "Innocence") may seem especially naive: since the reading focuses on aspects of Innocence, it will seem to miss aspects of Experience that subtly appear in them. This is justified by the idea that, by bringing to the fore the Innocent aspects of the poem from "Innocence," the ironic contrast with the Experience of its mirror poem will be more readily revealed. 


\section{Romantic irony in the introductory poems}

The pair of mirror poems analyzed is to be found in the "Introduction" in the "Innocence" section, and the "Introduction" in the "Experience" section, respectively. ${ }^{11}$ Here the poem "Earth's Answer," which immediately follows the second "Introduction" in the analysis, will also be considered. I am doing so because "Earth's Answer" explicitly dialogues with the "Introduction" from "Experience." "Earth's Answer" functions as a continuation of the second "Introduction," and does not work as well as a standalone poem. This means that the second "Introduction" and "Earth's Answer" are considered as a unity-this is how they are analyzed by Bloom (Blake's Apocalypse 129-132) and Gillham (153$156)$, among others. The plates immediately preceding the introductory poems of both sections in most editions, those depicting a man with a child above his head, one for each section, will also be considered, because they can be taken as yet more illustrations of these mirror poems. This set of plates and poems which will be analyzed were chosen precisely because of their complexity, by bringing together several pictorial and textual aspects.

Table 1. First "Introduction"

\begin{tabular}{|l|l|}
\hline Piping down the valleys wild & Piping songs of pleasant glee \\
On a cloud I saw a child. \\
And he laughing said to me.
\end{tabular}


The first "Introduction" brings a piper as the speaker, who enjoys himself making music in the midst of nature ("Piping down the valleys wild / Piping songs of pleasant glee"). He encounters a child on a cloud, who asks/demands him to play some music, and who disappears after some demands, leaving the piper writing the songs that "Every child may joy to hear." The poem, in an Innocent reading, is revealing of an attitude towards life that reveal the speaker's Innocence. The piper is happy, as his diction emphasizes, with word choices such as "pleasant glee," "joy," "laugh," "happy." He is also inspired, being able to either pipe, sing, and write down his artistic creation with no effort at all.

The demands of the child ("Pipe a song about a Lamb," "Drop thy pipe thy happy pipe") are demands for a merry gratification with music, which the piper readily fulfills. Their dialogue, then, is productive for both sides: the piper creates music and the child enjoys himself with it. The joy of the child is so great that he "wept with joy:" their communion in the artistic spontaneity of the situation is what makes possible this intense happiness. When the piper is left alone to write his songs, he readily makes a "rural pen," using what is available from nature: "a hollow reed," and some coloring extract, we suppose, mixed with water ("I stain'n the water clear").

The productive aspect of the dialogue between piper and child is emphasized in the plates: on each side of the text, a tree, with what seems to a contemporary reader a sort of DNA shape, stands. The shape itself hints at a dialogue, with approach and distancing, but which ultimately creates an organic being, the tree itself. Both trees also touch on the top of the page, hinting at a higher connection. The small designs inside the tree frames seem to depict persons and nature together (the kind of union depicted in the last stanza).

Table 2. Second "Introduction"

Hear the voice of the Bard!
Who Present, Past, \& Future sees
Whose ears have heard,
The Holy Word,
That walkd among the ancient trees.
Calling the lapsed Soul
And weeping in the evening dew:
That might controll,
The starry pole;
And fallen fallen light renew!
O Earth O Earth return!
Arise from out the dewy grass;
Night is worn,
And the morn
Rises from the slumberous mass.
Turn away no more:
Why wilt thou turn away
The starry floor
The watry shore
Is giv'n thee till the break of day.
(Blake 18)


Figure 4 L 31 - Second "Introduction" Source: www.blakearchive.org/copy/songsie. l?descId=songsie.l.illbk. 31

If the first "Introduction" brings a productive, spontaneous dialogue, the one from "Experience," when paired with its dialogical counterpart, "Earth's Answer," brings instead an unsuccessful dialogue. In the beginning of this "Introduction," the speaker presents himself as "the Bard," in the very first verse ("Hear the voice of the Bard!"). He has a prophetic vision, seeing "Present, Past \& Future," and grants to himself the authority of having heard "The Holy Word, / That walk'd among the ancient trees."

The second stanza creates a syntactic undecidability which further complicates its problems of communication (Ferber 1991, 21). It is impossible to decide who is "Calling the lapsed Soul / And weeping in the evening dew." It is either the Bard or the Holy Word, i.e. either the subject or the object of the earlier sentence, and in a sense a conflation of both is being made.

The second half of the poem is an intimation to the Earth. The Bard's plea is that the Earth "Arise from out the dewy grass" and "Turn away no more." From his words, a great deal of sexual tension is perceived. It is as if the Bard is trying to woo the Earth, who seems to act like a coy mistress: he asks her to return and stop turning away. In order to convince the Earth, the Bard gives reasons: in the third stanza, he says that the morning is rising; in the fourth stanza, he hints at her possibilities if she acquiesces to his wish: she will have "The starry floor / The wat'ry shore" to herself.

I use the feminine to refer to the Earth advisedly, since the design of this plate can be interpreted as her depiction. The image of the woman seductively looking over her shoulders shows how the Bard sees the Earth: sensual, but distant. The flower or blanket in which she is laid down is also suggestive of sexuality, resembling a vulva. If the Bard sees the Earth in this sexual way, that does not seem to be so when it is actually the Earth talking. The Bard already hints at Earth's despair, when he commands her to rise "from the slumberous mass." But his fascination with the Earth's sexuality (especially depicted in the design) does not allow him to see her actual state of sadness, which he takes as a kind of sexual game played by her. Her situation becomes obvious in the first stanza of the following poem, "Earth's Answer:" "Earth raisd up her head. / From the darkness dread \& drear." This is not the attitude of a coy mistress, but of someone in actual pain, dismissing the Bard's wooing not out of timidity, but out of "grey despair." 
Table 3. "Earth's Answer"

Earth rais'd up her head,
From the darkness dread \& drear.
Her light fled:
Stony dread!
And her locks cover'd with grey despair.
Prison'd on watry shore
Starry Jealousy does keep my denunciation
Cold and hoar
Weepin oer
I hear the Father of the ancient men
Selfish father of men
Cruel jealous selfish fear
Can delight
Chain'd in night
The virgins of youth and morning bear.
Does spring hide its joy
When buds and blossoms grow?
Does the sower?
Sow by night?
Or the plowman in darkness plow?
Break this heavy chain,
That does freeze my bones around
Selfish! Vain!
Eternal bane!
That free Love with bondage bound.
(Blake 18-19)

To the Earth, "The starry floor" becomes a "Starry Jealousy," and "The watry shore" makes her a prisoner. That is to say, if the Bard is trying to woo her with the stars and the waters, she throws them back at him with her claims of jealousy and captivity. Earth's bitterness is especially directed to "the father of the ancient men"- the epithet bringing to mind the God of the Old Testament. To her he is "Cruel jealous selfish," since He keeps the "delight / Chain'd in night." With this He separates sexual delight from what should be the normal life, by turning it into something secretive. In this, God seems to be recurring to the Christian dualism of body/soul-something that Blake openly criticizes on The Marriage of Heaven and Hell (Blake 34). This God, then, is a tyrant, making a wholly inadequate distinction (body/soul) that creates oppression and pain.

The last stanza is ambiguous, as it is impossible to assert to whom the Earth is talking. She is either talking to God or to the Bard. If she is talking to God, the reader knows, as well as the Earth herself, that her words are useless, and become just an actualization of her sad bitterness. If, on the other hand, the Earth is talking to the Bard, she throws all of his wooing back to him. Whether it is 
God or the Bard who is the interlocutor of the last stanza, the fact is that Bard and Earth cannot understand each other. Better yet, the Earth may understand the Bard in his alienated and sexually driven pursuit, but the Bard certainly cannot understand her. This miscommunication is one of the causes of the Earth's despair. Also, such miscommunication, and the non-resolution occurring in the last stanza, creates a dichotomy.

If we take now both "Introduction" poems and contrast them, this aspect of communication is perceptibly contrary in them. The miscommunication, and the lack of dialogue of the second "Introduction," emphasizes the constructive dialogue, and the effectual interplay between the piper and the child in the first one, and vice-versa. One poem ironizes the other: considering the communication presented in the first poem as the ideal, the second poem, together with "Earth's Answer," antithetically ironizes this ideal. This is done in the very division which occurs between the second "Introduction" and "Earth's Answer," if compared with the unity of the first "Introduction." It is also present on the syntactic ambiguity of the latter poems, when contrasted with the syntactic clarity of the first "Introduction." Such lack of communication is a given in the world of Experience, but the utter lack of communication of second poem and "Earth's Answer" is also questioned by the possibility of it in the first one, as the piper and the child create a dialogue of demands and answers that is acceptably fulfilled. In this sense, the aspect of communication of both "Introduction" poems does not need to be seen as a dichotomy in the same way as the dialogue between the Bard and the Earth. Even though such views are irreconcilable, a dialectical process can be seen as hovering between them.

Considering this aspect of communication, a fragment by Schlegel is enlightening: he says that Socratic irony "contains and arouses a feeling of indissoluble antagonism between the absolute and the relative, between the impossibility and the necessity of complete communication" (156). The key concept here is "complete communication," the sort of communication seen in the first poem, and relativized in the second one. The antagonism to which Schlegel refers is similar to the one present in the poems. In the first poem, the "complete communication" takes place, while in the poems from "Experience" the impossibility of such communication is revealed.

The same way the poems dramatize Schlegel's quotation, they can be seen as dramatizing the concepts of self-creation and self-annihilation. The self-creation of the first poem (spontaneous, intuitive interchange and artistic creation) is contrasted with the second "Introduction" and "Earth's Answer" in that they criticize, by the depiction of a completely failed interchange, the possibility of the "complete communication." Such critique is the self-annihilation. And with this critique in mind we can come back to some aspects of the first poem that may have sounded dubious and ironize them: the child's weeping may not be an innocent joy, but a disconnection between him and the piper; the staining of "the water clear" may not be because of the creation of an ink, but a metaphorical staining, as it further perpetuates a disconnection. 
Another aspect of the poems which can be contrasted is the way in which both speakers refer to themselves. In fact, the first speaker, the piper, does not refer to himself at all, but lets the child name him. The Bard, on the other hand, proudly presents himself in the very first verse of his poem. The piper is just someone who plays the pipe, his action at the moment, and not a definition of his being, as he will also become a writer by turning a "hollow reed" into a "rural pen." It is also impossible to take from the word "piper" the same connotations of status associated with the word "Bard." "Bard" carries with it a much stronger traditional, institutionalized sense-one thinks of Shakespeare's epithet, for instance. Such aspects are encountered in the poems of the respective speakers: the piper simply pipes merry songs, and makes the child happy; the Bard, on the other hand, evokes his authority ("Whose ears have heard / The Holy Word") and makes commanding solicitations to the Earth. Piper and Bard impersonate two modes of poetic creation: the first incarnates a mythical origin of poetry, and the second carrying a tradition on his back or in his head. They are, to use Friedrich Schiller's concepts, a naive poet and a sentimental poet, respectively.

More related contrasts can be seen in the two plates depicting a man with a child above his head. The plates accompany the introductory poems of each section, and their similarities, as well as their differences, are yet more elements to be considered together with the introductory poems. The scene in itself of both is very similar (trees and sheep grazing in the background, a man and a child in the front), and seems to be there to reinforce the differences, and to make the reader consider them.

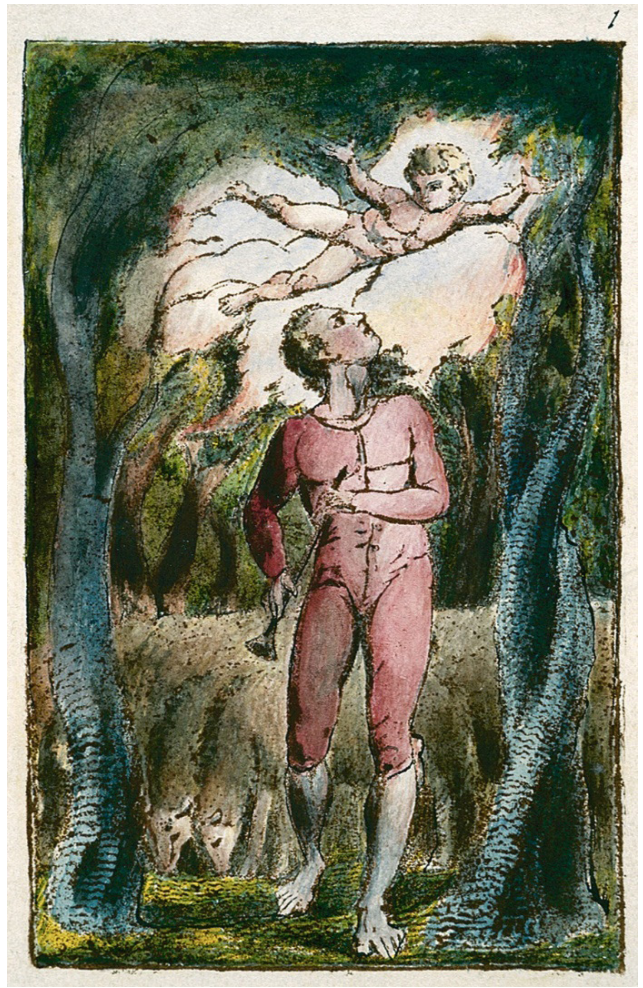

Figure 6. L 1 - Illustration from Innocence Source: www.blakearchive.org/copy/songsie.l?d escId=songsie.l.illbk.01

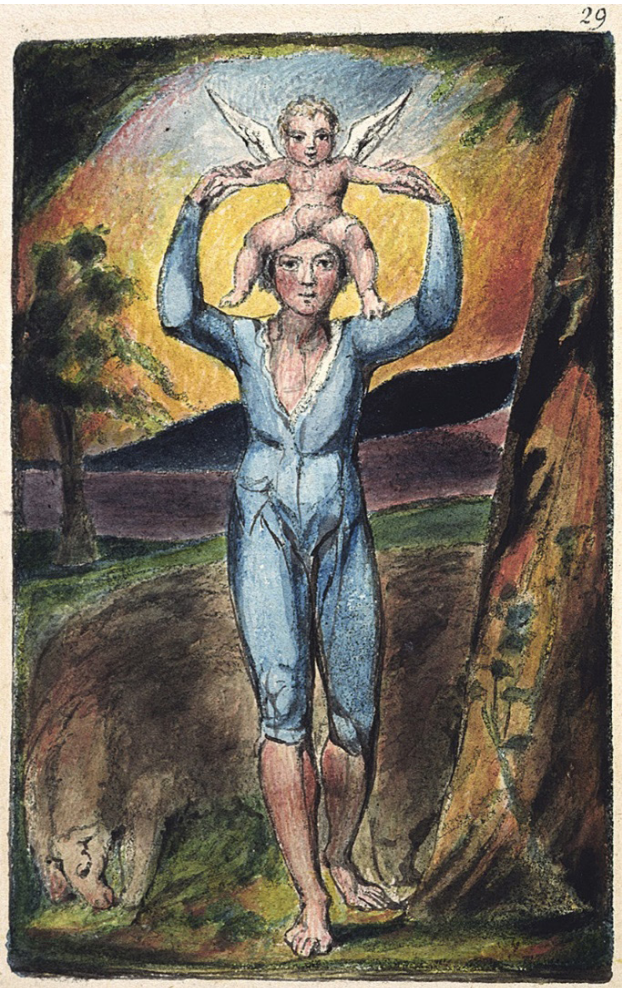

Figure 7. L 29 - Illustration from Experience Source: http://www.blakearchive.org/copy/songsi e.l?descId=songsie.l.illbk.29 
In the first plate, a piper stares amazed at a flying child, who has his arms spread as if to show its majesty. The child is flying, but has no wings, and what can be a branch of a tree or the outline of a cloud is suggestively close to his navel, as if it was a recently-cut umbilical cord. Two trees frame the man and the child more or less symmetrically, with the right one having the same sort of DNA shape found in the trees framing the first poem. The second plate, on the other hand, depicts a man holding a child above his head, this time a winged child. Both of them have expressions in their faces which hint at tiredness and conformity. Two trees also appear, but the one on the right is much closer than the one to the left.

An ironic contrast is revealed when one looks at both children: the winged child is not flying, while the wingless child is flying. A possibility for this is that Innocence depicts the child ideally, a newborn in all of his magnificence, effortlessly flying as if to show his tremendous potentiality; Experience, on the other hand, depicts the child's latent power in his wings, but needs to give him a direction, or perhaps more forcefully, feels the need to conform him to its own state. This is related to aspects in both poems: a) in the first one, to the dialogue of the piper and the child, which has an efficient communication, and, if there is a hierarchy, the child is higher, asking for actions which the naive poet (piper) promptly performs; b) in the second one, to the way in which the sentimental poet (Bard) claims to himself, as if securing it with him, the authority (or the Bard's tradition) displayed in the first two stanzas.

The trees in both designs are also significant. In the first one, they give to the plate symmetry and balance-something that also occurs in other poems from "Innocence," such as "The Lamb." In the second one, a hierarchy is created between them because of their relative distance to the front of the picture. The symmetry of the first one converges with the efficient communication in the first poem. For the second one, it is not so much a matter of relating each tree to one of the speakers or to God, but to notice that this hierarchization is present, and is probably actualized by each speaker (Bard and Earth) differently. The distance between these trees, when contrasted with the ones from the first plate, are reminiscent of the distance between the Bard and the Earth.

\section{Final Remarks}

The "Introduction" poems from "Innocence" and "Experience," along with "Earth's Answer" and the two plates which illustrate them, are not supposed to be representative of the whole of mirror poems in Songs. Even though they inaugurate each section, and bring themes and a kind of diction that permeates poems from each section, they do not represent the whole volume in all its intricacies. The readings, however, illustrate the way an approximation with Schlegel's Romantic irony can be profitably used to read the other mirror poems. Moreover, the readings carried out are not necessarily close to Blake's intentions. As mentioned before, Blake and Schlegel most probably never read each other's works-not to mention that Schlegel developed his concept of Romantic irony 
after the writing of Songs. Both, however, seem to share an affinity for a dialectical way of understanding the world. Blake's famous quote "Without Contraries is no progression" is revelatory of this (Blake 34).

The approximation with Schlegel's Romantic irony is a way of bringing the often-mentioned irony of the Songs together with the progressive character of the states of Innocence and Experience. If Innocence brings intuition, joy, purity, Experience comes and ironically contrasts this with bitterness and despair. This does not mean that the poem from "Experience" is a conscious retort to the one from "Innocence," as if the speaker was trying to ironically answer the one from "Innocence." While something like this happens more explicitly in a pair not analyzed here ("The Divine Image" and "The Human Abstract"), in most mirror poems, it seems more like Blake himself is contrasting these two very different speakers, and with this contrast creating irony.

As I argued in my analysis, the mirror poems can be seen as dramatizing Schlegel's self-creation and self-annihilation. And with both side by side, something other than either contrary state can be thought. Their contrasts create what is in Schlegel the self-restriction, and in Blake an "organized, higher innocence" (Bloom Blake's Apocalypse 20). The naive piper and the sentimental Bard are conjoined in this synthesis.

Such readings show complexities of Blake's poems which a reading that focuses on the predominant state of each poem (e.g. focusing on Innocence in a reading of "The Little Black Boy," or on Experience in a reading of "The Tyger") cannot. This complication goes in tandem with a passage from Schlegel, when analyzing his brother's Elegies: "a classical text must never be entirely comprehensible. But those who are cultivated and who cultivate themselves must always want to learn more from it" (Schlegel 269). The readers are then able to perceive (or to create) in such texts-and I believe Songs can be put in this category-a degree of complexity, of paradox, and of Romantic irony itself.

Notes

1. From here on, I will refer to this book as Songs, not to be confused with the separate volumes Songs of Innocence and Songs of Experience.

2. Not all of the extant copies are painted, although most of them are. Most of the copies can be accessed digitally, in high-resolution images, on The William Blake Archive (http://www.blakearchive.org) website, which is where the plates included in this paper are taken from.

3. I will use throughout this paper Copy L of Songs of Innocence and of Experience. The copy is currently at the Yale Center for British Art. The title of the picture (L 3 - Songs of Innocence Cover) refers to the copy (L) and the number of the object (3). The same pattern is used when referring to other plates.

4. From here on I will refer to "Songs of Innocence" and "Songs of Experience" as, respectively, "Innocence" and "Experience," the two sections of Songs. They are not to be confused with the states of Innocence and Experience.

5. I borrow the term from W. J. T. Mitchell's Blake's Composite Art (1978), which successfully argues in favor of such view. 
6. "parábase;" "bufão" (I include my translations of texts in Portuguese in the body of the text and the originals in footnotes).

7. "o papel do dramaturgo."

8. “'autocriação' [Selbstschöpfung], 'autoaniquilamento' [Selbstvernichtung] e 'autolimitação' [Selbstbeschränkung]."

9. "ingênuo, entusiasta, inspirado, imaginativo."

10. Usually translated into English as "On Naive and Sentimental Poetry."

11. I will sometimes refer to these poems as first and second poems, meaning, respectively, the "Introduction" from the "Innocence" and the "Introduction" of "Experience."

\section{References}

Alford, Steven E. Irony and the Logic of the Romantic Imagination. Peter Lang Inc., 1984.

Baldick, Chris. The Concise Oxford Dictionary of Literary Terms. New York: Oxford UP, 2001.

Benjamin, Walter. O Conceito de Crítica de Arte no Romantismo Alemão. 1919. Translated by Márcio Seligmann-Silva. São Paulo: Iluminuras, 2018.

Blake, William. The Complete Poetry and Prose of William Blake. 1965. Edited by David V. Erdman. New York: Anchor Books, 1982.

Bloom, Harold. Blake's Apocalypse. New York: Doubleday, 1963.

The Visionary Company. New York: Cornell UP, 1971.

Booth, Wayne Clayson. A Rhetoric of Irony. The University of Chicago Press, 1975.

Colebrook, Claire. Irony. New York: Routledge, 2008.

Cuddon, J. A. A Dictionary of Literary Terms and Literary Theory. 1977. Chichester: John Wiley \& Sons, 2013.

Damrosch, Leo. Eternity's Sunrise. Yale University Press, 2016.

Erdman, David V. Blake: Prophet Against Empire. 1954. Dover Publications, 2015.

Ferber, Michael. The Poetry of William Blake. New York: Penguin Books, 1991.

Gillham, D. G. Blake’s Contrary States. 1966. New York: Cambridge UP, 2009.

Immerwahr, Raymond. "The Subjectivity or Objectivity of Friedrich Schlegel's Poetic Irony." The Germanic Review, vol. 26, n. 3, 1951, pp. 173-191.

Medeiros, Constantino Luz de. "A forma do Paradoxo: Friedrich Schlegel e a Ironia Romântica." Trans/Form/Ação, vol. 37, no. 1, 2014, pp. 51-70.

Muecke. D. C. A Ironia e o Irônico. 1970. Translated by Geraldo Gerson de Sousa. Brasil: Perspectiva, 2008.

Pamuk, Orhan. The Naïve and the Sentimental Novelist. Translated by Nazim Dikbas. New York: Vintage International, 2011.

Phillips, Michael. William Blake: Master \& Apprentice. Oxford: Ashmolean, 2014.

Schlegel, Friedrich. Lucinde and the Fragments. Translated by Peter Firchow. Toronto: University of Minnesota Press, 1971.

Seligmann-Silva, Márcio. Introduction. O Conceito de Crítica de Arte no Romantismo alemão, by Walter Benjamin, 1919. São Paulo: Iluminuras, 2018, pp. 9-14. 
Simpson, David. Irony and Authority in Romantic Poetry. Totowa: Rowman and Littlefield, 1979.

Viscomi, Joseph, and Morris Eaves. "Illuminated Printing." The Cambridge Companion to William Blake, Cambridge University Press, 2004, pp. 37-62.

Recebido em: 14/07/2020 Aceito em: 16/11/2020 